\title{
A paper on development and standardization of electronic booklet on indigenous knowledge about home practices
}

\author{
PRASANLATA ARYA AND RAJENDRA RATHORE
}

Received: 25.03.2017; Revised: 19.09.2017; Accepted: 05.10.2017

See end of the paper for authors' affiliations

\section{PRASANLATA ARYA}

College of Home Science, S.K. Rajasthan Agricultural University, BIKANER (RAJASTHAN) INDIA

Email : 19prasanlata.arya@ gmail.com
ABSTRACT : The present study was conducted in Bikaner district of Rajasthan. For selection of rural and urban respondents, two panchayat samities i.e. Bikaner and Nokha for rural and two zones i.e. east and west for urban was selected. The women above 50 years of age was selected from each village and each ward. A sample of 240 respondents comprising 120 respondents from rural area and 120 respondnets from urban area were selected randomly. Further sixty literate women (30 rural +30 urban) were selected for the effectiveness of e-booklet. The study was conducted in the four major aspect i.e. documentation of indigenous knowledge regarding home practices, expert opinion regarding documentation indigenous practices, development and standardization of e-booklet and field test of developed e-booklet. Findings shows that indigenous knowledge regarding food practices the majority of respondents were engaged in drying of clusterbeans (89.58\%) in vegetable group $(95.83 \%)$ were from rural area and $(83.33 \%)$ were from urban area, prepared the pickle of green chilli by all rural and urban respondents with use of oil and condiments and the majority (70.83\%) of urban respondents prepared Amla murabba and nimbusharbat with the use of sugar. All these practices considered logically correct by all expert. The developed e-booklet on indigenous knowledge was standardized on the basis of quality parameter was perceived quite high in terms of its content, format found reliable and applicable in the field. The readability and comprehension was also found high.

KEY WORDS: Indigenous Knowledge, Documentation, Practices, Development, Standardization

- HOW TO CITE THIS PAPER : Arya, Prasanlata and Rathore, Rajendra (2017). A paper on development and standardization of electronic booklet on indigenous knowledge about home practices. Asian J. Home Sci., 12 (2) : 355-359, DOI: 10.15740/HAS/AJHS/12.2/355-359. 